\title{
Words, Dates, Statistics, Money
}

\section{PRONOUNCING TSUKIJI}

Many foreigners stumble over the pronunciation of "Tsukiji," the name of both the market and the neighborhood that surrounds it. "Tsukiji" roughly rhymes with "squeegee." The "ts" sound (like "tsetse fly" in English) is difficult for many foreigners, and the vowels are elided. Americans often mispronounce the name by applying stress: tsu-KI-ji. But in Japanese, all syllables receive equal emphasis.

\section{PEOPLE'S NAMES}

All individuals mentioned in the text of book are identified by pseudonyms, except for public figures and published authors. The names of Japanese individuals are presented in the Japanese fashion: family name first, personal name second.

\section{TERMS}

A glossary of Japanese terms, particularly the specialized vocabulary of a wholesale seafood market, appears in the back of the book. The most extensive and detailed English-language glossary of Japanese culinary terms, foodstuffs, and techniques is modestly titled A Dictionary of Japanese Food, by Richard Hosking (1996). Other good glossaries can be found in Condon and Ashizawa (1978) and Richie (1985).

Two major sets of actors at Tsukiji are the nakaoroshi gyōsha (also sometimes called nakagai or nakagainin) and the oroshi gyōsha. Although these terms are translated in a variety of ways in the seafood industry, I refer to 
them throughout the book as "intermediate wholesalers" and "auction houses" respectively.

Tokyo was known as Edo until the Meiji Restoration of 1868 . Throughout the book I refer to the pre-Meiji city, bay, and castle as Edo.

\section{Abbreviations}

I use the following abbreviations in the text and in citations:

MAFF Ministry of Agriculture, Forestry and Fisheries (Nōrinsuisanshō, in Japanese)

TMG Tokyo Metropolitan Government (Tōkyō-to, in Japanese)

\section{Transliterations and Translations}

Japanese terms commonly used in English—sushi, sashimi, saké-are not italicized, and well-known place-names - Tokyo, Osaka, Kyoto-are written without diacritical markings, unless they appear in a Japanese phrase or as part of a proper name. All other Japanese terms are written with appropriate diacritical markings. Japanese words in the body of the text are italicized only on first use in a chapter, except when the word itself is the subject of discussion. Japanese words are transliterated according to the system used in Kenkyüsha's New Japanese-English Dictionary (4th ed.).

All translations from Japanese sources are my own.

\section{DATES}

Japanese history is conventionally divided into periods based on dynastic names and individual imperial reigns. Just as Americans use time periods to imprecisely identify social and cultural milieu ("the Roaring Twenties," "the sixties"), Japanese identify events and trends with similar blocks of time, which often do not translate meaningfully into Western historical contexts. Where possible, I provide specific dates in Western terms, but the following era names are also used:

Tokugawa period

Meiji period

Taishō period Shōwa period

Allied Occupation period

Heisei period

$$
\begin{aligned}
& 1603-1868 \\
& 1868-1912 \\
& 1912-1925 \\
& 1926-1989 \\
& 1945-1952 \\
& 1989 \text { to the present }
\end{aligned}
$$

The "postwar" period in Japanese history is often vaguely defined, sometimes meaning anything after 1945; from the perspective of the beginning of the twenty-first century, the term more appropriately applies to the period of 
postwar recovery, and I use the term to refer to the late 1940s, 1950s, and early 1960s (arbitrarily ending it with the 1964 Tokyo Olympics).

\section{STATISTICS}

Markets change quickly, and nowhere more so than in the statistical yardsticks by which they are often measured and recorded. I do not attempt to provide complete statistical coverage over the span of my fieldwork from the spring of 1989 through the summer of 2003 (when the final copyediting of this manuscript was completed). The never-ending problem is how to draw statistics on changing conditions to a conclusion.

I have tried whenever possible to provide statistics from the approximate beginning, middle, and end of my fieldwork, to indicate trends rather than rely on stand-alone statistical snapshots. I have also tried to obtain statistics from as close to 2003 as possible, but in many cases the most recent available statistics may reflect conditions in 2000, 2001, or 2002. (Market figures often are reported on the basis of the Japanese fiscal year, which begins April 1 and ends March 31.)

Readers who want even more up-to-date statistics on the market's performance should consult the published sources and websites listed in appendix 2, including my own website, www.people.fas.harvard.edu/ bestor/ tsukiji, where I will post selected statistics and other information about Tsukiji.

\section{MONEY AND FOREIGN EXCHANGE}

Changes in the exchange rate of the U.S. dollar vis-à-vis the yen make discussion of monetary values tricky. Historically, the yen-dollar exchange rate before World War II was two yen to the dollar. After the war, the exchange rate was pegged at 360 yen to the dollar, which remained the stable rate until what the Japanese refer to as "the Nixon shocks" of the I970s. Over the course of my research, from 1989 to 2003, the average exchange rate fluctuated dramatically (Nihon Tōkei Kyōkai 2003: 430):

$\begin{array}{llll}1989 & ¥_{130}=\$ 1.00 & 1996 & ¥_{106} \\ 1990 & ¥_{150} & 1997 & ¥_{120} \\ 1991 & ¥_{135} & 1998 & ¥_{130} \\ 1992 & ¥_{130} & 1999 & ¥_{118} \\ 1993 & ¥_{118} & 2000 & ¥_{106} \\ 1994 & ¥_{107} & 2001 & ¥_{119} \\ 1995 & ¥_{93} & & \end{array}$


In July 2002 and July 2003, the rate stood at about $¥_{117}$ and $¥_{118}$, respectively.

These annual averages themselves sometimes smooth over rapid fluctuations in exchange rates from month to month. Foreign exchange rates are critical for many aspects of Tsukiji's business, and exchange rate risk can amplify market risk to create extreme volatility in the marketplace. However, since this research is not a price-based economic analysis, I usually report values in unadjusted yen wherever possible, without dollar equivalents unless to give non-Japanese readers a sense of scale. 